\title{
YURY I. VENELIN AND HIS HISTORY OF THE AINCIENT AND MODERN BULGARIANS ${ }^{1}$
}

\begin{abstract}
:
The article highlights the life and academic activities of Y.I. Venelin (1802-39), the founder of Russian-Bulgarian studies and his work in the Moscow Society of History and Russian Antiquities. He made the first professional trip to Bulgaria, but the materials he collected were only published after his death. Most historians (including the famous P.J. Shafarik) were very critical of Venelin's essays "History of the Ancient and Modern Bulgarians in their Political, Folk, Historical and Religious Relation to the Russians" (1829). But for Bulgarian society during the period of its national revival, the essays had a special importance and made a huge impact. Nowadays the works of Venelin have attracted attention again, which has resulted in their republications.
\end{abstract}

\section{Keywords:}

Y.I. Venelin, I.I. Molnar, M.P. Pogodin, Moscow Society of History and Russian Antiquities, Bulgarian revival.

АННОтация: М.М. ФРОЛОВА. «ЮРИЙ И. ВЕНЕЛИН И ЕГО ИСТОРИЯ ДРЕВНИХ И НЫНЕШНИХ БОЛГАР».

В статье освещаются жизненный путь и научное творчество зачинателя русской болгаристики Ю.И. Венелина (1802-39), его деятельность в Обществе истории и древностей российских. Он совершил первую научную командировку в Болгарию, но собранные им материалы были опубликованы лишь после его смерти. Большинство историков (в том числе и знаменитый П.Й. Шафарик) весьма критически отнеслись к сочинению Венелина «Древние и нынешние болгаре в политическом, народописном, историческом и религиозном их отношении к россиянам» (М., 1829). Но для болгарского общества периода национального Возрождения оно имело особую значимость и оказало на него огромное влияние. В настоящее время труды Венелина вновь привлекают внимание, что выражается в их переиздании.

\section{Ключевые слова:}

Ю.И. Венелин, И.И. Молнар, М.П. Погодин, Общество истории и древностей российских, Болгарское возрождение.

Y ury Ivanovich (George Hutsa) Venelin (1802-39) was an amateur scholar and pioneer of Russian-Bulgarian studies, who caused Bulgarians to take a fresh look at their history and awakened in them a sense of national pride.

He was born into the family of a Transcarpathian village priest, I. Hutsa. The village of Tibava (or Great Tibava, Big Tibava), along with Transcarpathia, was

\footnotetext{
1 The work was carried out with the financial support of the RFBR (grant № 18-512-76004).
} 
then a part of the Austrian Empire. After the Second World War it was annexed to Ukraine, one of the 15 republics of the Soviet Union. After graduating from gymnasium in Ungvar (now Ukrainian Uzhgorod), George Hutsa entered the local theological seminary, then studied at the Episcopal Lyceum in Satmar (now Satu Mare, Romania) with his cousin, I.I. Molnar, and from 1822 continued his education at the faculty of Philosophy at Lvov University. While still at the lyceum, Venelin began to write his first notes on the history of the Slavs, a topic which developed into a real passion. The young man showed an amazing ability to learn foreign languages: he knew ancient Greek and Latin well, spoke fluent Magyar (Hungarian), German and French, and understood English, Italian, Spanish and Walachian (Romanian) well. He also quickly mastered the Slavic languages.

A career as a Catholic priest stopped to seem appealing and, as a CarpathoRussian or "Rusyn" by origin, he felt himself to be Russian and dreamed of living

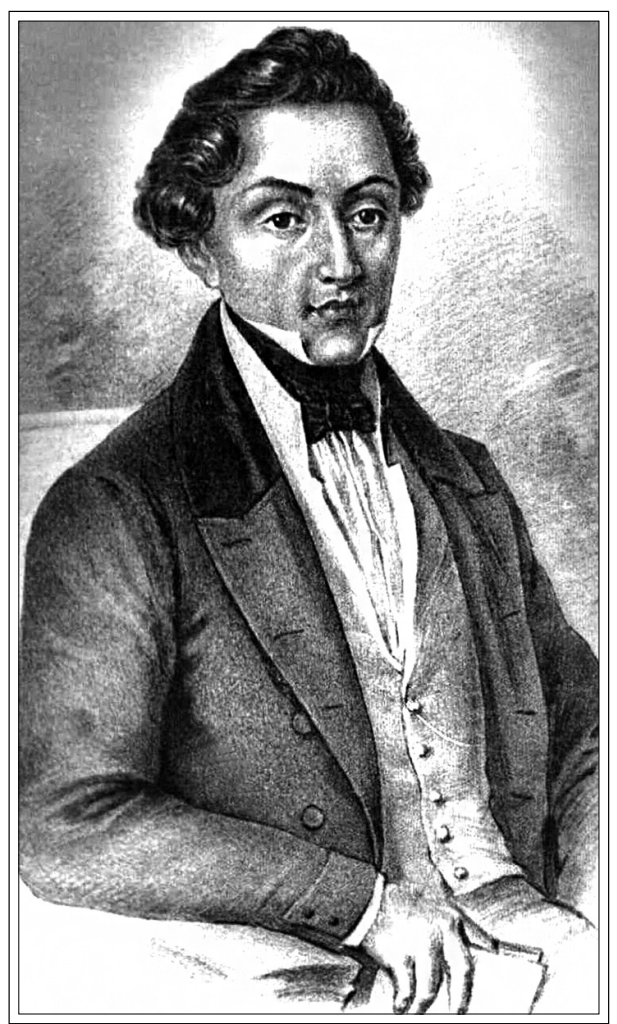

Yury I. Venelin

(1802-39) in Orthodox Russia. Upon moving to Russia, he changed his surname from Hutsa to Venelin. Together with Molnar, he first settled in Kishinev (1823-25) and then in Moscow, enrolling in Moscow University's medical faculty. Venelin successfully completed medical school in 1829 , but his love of history proved to be stronger than his love of medicine. This was encouraged in every way by a professor at Moscow University, the famous historian M.P. Pogodin (1800-75), who prompted Venelin to write the book "Ancient and Modern Bulgarians in their Political, Folk, Historical, and Religious Relation to the Russians." In 1829 Pogodin published it at his own expense, won over by the "childishly pure soul" of the author and his "dreams of the Bulgars." This work was very relevant, because at that time the Russo-Turkish war of 1828-29 was underway.

Thanks to help from acquaintances in Moscow and, particularly, from Pogodin, in 1830 he was sent on academic trip to Bulgaria by the Imperial Russian Academy. However, the conditions were unfavorable. According to the Adrianople Peace Treaty of 1829, Russian troops had by then left the Bulgarian lands. Venelin was able to visit only two war-ravaged Bulgarian cities: Varna and Silistra. On the positive side, his research in the archives of the Archdiocese of Bucharest 
proved fruitful: there the scholar discovered many documents in the Slavic language from 14 th to 17 th centuries, which he subsequently prepared for publication. Venelin's work, Walacho-Bulgarian or DacoSlavic Documents, received a favorable response from the academic A.Kh. Vostokov, though it was only published in 1840, that is, after the author's death, and long retained its academic importance.

The main purpose of Venelin's trip was to collect Bulgarian folk songs. The romantically inclined scholar believed folklore to be one of the most important sources of knowledge, not only of the character, customs and rites of the people, but also of its history. The fifty songs he collected were then included in Russian Slavicist P.A. Besonov's publication, Bulgarian songs from the collections of YuI. Venelin, N.D. Katranov and other Bulgarians (Moscow, 1855. Vol. 1-2).

One of the main results of Venelin's scientific journey to the Balkan peninsula was The Grammar of the Present Bulgarian Dialect, completed by the scholar in 1834 . However, the Russian Academy reacted negatively to it. It was published relatively recently: in 1997 it was printed by Russian philologist G. K. Venediktov.

In 1835 the Department of History and Literature of Slavic Dialects opened within the philological department of Moscow University's Faculty of Philosophy, whose head Venelin attempted to become. With this in mind, a year earlier he had created a "synopsis of teaching" of these disciplines, which was the first attempt to describe the course program of university-level Slavic studies. However, due to his lack of a degree in philology or history, Venelin did not have the right to head the department, according to the university's charter. Despite Pogodin's energetic support of Venelin's candidacy, Professor M.T. Kachenovsky (1775-1842) was selected as the chair. Venelin's manuscript of the program was itself published only in 1898. 
Venelin was very distressed by this series of failures but didn't abandon his academic studies. The scholar's only consolation was that his supporters in Moscow, who were members of the Society of History and Russian Antiquities (SHRA), elected him as a full member in 1832. Academic readings and discussions within the walls of SHRA continued at the literary evenings for which Moscow was famous in the 1830s-40s.

Venelin's sudden death in March 1839 shocked his friends and colleagues in SHRA. The publication of twelve of his scientific papers in the pages of the journal "Readings in the Society of Russian History and Antiquities" from 1846 to 1870 attests to their respect for him and his work. These papers were discovered in an archive of Venelin's works belonging to the Molnar family, and were then transferred to the SHRA, from where they ended up in the manuscript division of the Russian State Library. To date, about 70 of Venelin's writings, diary entries, and letters have been published.

Let us now turn to Venelin's famous book, "Ancient and Modern Bulgarians..." In the first quarter of the 19th century, academic research was dominated by the view of Western European scholars August Ludwig von Schlözer, Johann Christian von Engel, Johann Erich Thunmann et al., who believed that the Bulgarian horde of Khan Asparukh, which had come to the Balkans in the seventh century, was of Turkish-Tatar origin. Having settled among the Slavs, they blended into them, but left them their name, "Bulgarians." This point of view was shared by Russian historians N.M. Karamzin, M.T. Kachenovsky, et al. As for Venelin, he passionately defended the concept of the Slavic origin of the ancient Bulgarians and simultaneously refuted the idea of the Norman roots of the Russian people, constructed according to a similar scheme. He argued that the Bulgarian Slavic state had existed since ancient times, and its beginnings were lost in the chaos of the so-called Scythian world. The Turks overthrew this state at the end of the 14 th century, but the Bulgarian people themselves did not disappear. There was simply little information about them, so the Europeans forgot about the Bulgarians. For this reason, they lost not only their statehood but also their history. The paucity of historical evidence and facts and the insubstantial exploration of the topic, combined with Venelin's ardent and romantic nature, caused him to speculate about many things using the power of his imagination. This work was not favorably received in academic circles.

The courage and novelty of the Venelin's ideas that the Slavs, prior to the sixth century, lived under other names won over N.P. Pogodin. He averred that none of the historians, who were trained in Schlözer's strict methodology, ever considered the historical existence of these people before the appearance of information about it in the chronicles and did not dare to look for traces of its existence before the sixth century.

However, everything changed when the Bulgarians discovered Venelin and his work; initially, these were Bulgarian emigrants living in Russia. This work had an extraordinary effect on them. Many of them had previously been ashamed 
to admit their Bulgarian origin and had posed as Greeks. By virtue of his talent and love for Slavs, Venelin proved, first of all to the Bulgarians themselves, how splendid were the people to whom they belong, and how magnificent their history was. At the same time, he wrote about how sad it was that the Bulgarians' fate was now under the yoke of the Turks, that these glorious people are suffering under spiritual dominance of the Greeks and the deplorable state of education. The increased national self-awareness by representatives of the Bulgarian emigres encouraged them to work toward educating their people. V.E. Aprilov (1789-1847), a russified Bulgarian from Odessa and previously zealous hellenophile, together with his countrymen, rich Bulgarian merchants N. Palauzov and H. Mustakov, created a charitable institution to raise funds to construct a new type of secular Bulgarian school in the city of Gabrovo, i.e., within the territory of the Ottoman Empire. It became a model for other new educational institutions created in Bulgaria, which replaced the so-called "cell" elementary schools at monasteries and churches. Venelin's writings are representative of an entire era in the Bulgarian national consciousness. They were reflected in the work of such prominent figures of the Bulgarian national revival as G.S. Rakovsky, R. Zhinzifov, L. Karavelov, S. Palauzov, M. Drinov, D. Voynikov, V. Drumev, Petko Slaveykov, D. Chintulov, etc.

Venelin's death was regarded by many Bulgarians as that of someone close to them. The poet G. Peshakov, who had previously praised the scholar in an ode, responded to his death with a mournful poem, "Weeping at the death of YuI. Venelin." It was no accident that in 1841 the Odessa Bulgarians, at their own expense, erected a monument on the grave of the scholar in Moscow's St. Danilov Monastery. The inscription carved on it read: "To Yury Ivanovich Venelin from the Odessa's Bulgarians. Born 1802 - died 1839. He reminded the world of the forgotten, but once glorious, powerful tribe of Bulgarians and ardently wanted to see its rebirth. Almighty God! Hear the prayer of your servant." Unfortunately, this tombstone did not survive, however, the scholar's memory continues to live on in Bulgaria: surprisingly, his surname has become a common first name which many Bulgarians have chosen for their children.

Translated by Igor Kaliganov

\section{BIBLIOGRAPHY}

Baytsura T. Yuriy Ivanovych Venelin. Bratislava, 1969. 174 p.

Frolova M.M. "Yu.I. Venelin i Obshchestvo istorii i drevnostey rossiyskikh." In: Slavyanskiy mir v tret'yem tysyacheletii. Mezhkul'turnyy i mezhkonfessional'nyy dialog slavyanskikh narodov. Moscow, 2011. S. 143-151.

Gachev G.D. "«Drevniye i nyneshniye bolgare» Venelina kak nauchno-khudozhestvennoye proizvedeniye i natsional'nyi mif." In: Yu.I. Venelin v Bolgarskom Vozrozhdenii. Moscow, 1998. S. 27-51.

Lapteva L.P. Istoriya slavyanovedeniya v Rossii v XIX veke. Moscow: Indrik, 2005.847 s. 
Nikulina M.V. "Puteshestviye Yu.I. Venelina v Bolgariyu i yego mesto v nachal'noy istorii bolgaristiki v Rossii”. In: Yu.I. Venelin v Bolgarskom Vozrozhdenii. Moscow, 1998. S. 122-47.

Smol'yaninova M.G. "Yuriy Venelin i bolgarskaya literatura epokhi natsional'nogo Vozrozhdeniya." In: Yu.I. Venelin v Bolgarskom Vozrozhdenii. Moscow, 1998. S. 5-26.

Venediktov G.K. "O puteshestvii Yu.I. Venelina v Bolgariyu". In: Uchenoye puteshestviye Yu.I. Venelina v Bolgariyu (1830-1831). Moscow, 2005. S. 3-16.

\section{ILLUSTRATIONS}

1. Yury I. Venelin (1802-39).

2. A peasant house of the late 18th century in the village of Tibava. The inscription on the memorial plaque reads: "According to one hypothesis Yury Venelin-Hutsa was born in this house in 1802."

3. The title page of the book "Ancient and Modern Bulgarians in their Political, Folk, Historical, and Religious Relation to the Russians." Moscow, 1829.

4. The title page of the book "Ancient and Modern Bulgarians in their Political, Folk, Historical, and Religious Relation to the Russians." Moscow, 1856.

5. Ivan I. Molnar. A portrait of the artist S.I. Hlobystov, 1840.

6. Moscow University, created in 1755. First quarter of 19th century.

7. Mikhail P. Pogodin (1800-75). Lithograph. Prague, 1846.

8. Vasil Aprilov (1789-1847), the Russified merchant of Bulgarian origin who lived in Odessa.

9. Yu.I. Hutsa-Venelin; a memorial plaque in the town of Svalyava.

10. Memorial plaque-centographer to Yu.I. Venelin on the northern wall of the St Danilov Monastery in Moscow. The monastery cemetery, where the scholar was buried, was destroyed by the Bolsheviks after the 1917 revolution. 